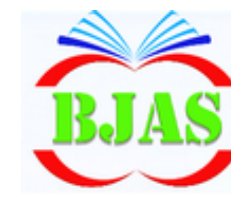

ISSN 1814 - 5868
Available online at http:/bajas.edu.iq

https://doi.org/10.37077/25200860.2020.32.1.01

College of Agriculture, University of Basrah

Basrah J. Agric. Sci., 33(1): 1-16, 2020
Basrah Journal

of Agricultural

Sciences

E-ISSN: 2520-0860

\title{
Risk Assessment of Drifting Sand in Agricultural Lands in Basrah Province with the aid of ' $3 S$ ' Techniques
}

\author{
Mushtak T. Jabbar ${ }^{1, *}{ }^{*}$ Eric M. Baer ${ }^{1}$ \& Salah M.S. Al-Atab ${ }^{2}$ \\ ${ }^{1}$ Geology Department, Earth Sciences, HCC/ Seattle, Washington, 98198 USA \\ ${ }^{2}$ Department of Soil Science and Water Resources, University of Basrah, Iraq \\ *Corresponding author-mail: mushtak1967@yahoo.com
}

Received 19 September 2019; Accepted 22 March 2020; Available online 20 June 2020

\begin{abstract}
There is a growing need to systematically assessment of drifting sand risk using Geo-information and related technologies for speed and accuracy. The drifting sand map in the southern part of Iraq was established with objective of providing the risk areas of soil loss and the methodology for spatial modeling with Wind Erosion Equation (WEQ) and Geo-information techniques. This analysis was carried out using ' $3 \mathrm{~S}$ ' technologies [Remote Sensing (RS), Geographic Information System (GIS) and Global Position System (GPS)], with the layers extracted and manipulated from available topographic, climatic and soil maps, as well as satellite image (Thematic Mapping (TM) in 2003 and Enhanced Thematic Mapping (ETM) in 2016) and field survey data analyses. Each of the WEQ factors was digitally encoded in a GIS database to establish each factor's layers. Simultaneously, the overlay operation with the WEQ model on the factor's layers was digitally performed to produce the sandy degradation class. The study indicated that the severe erosion class covering an area of about $61.9 \%$ of the total area is very high with the degraded vegetation and is located in the southwest part of Iraq. Iraq faces serious environmental degradation problems that must be addressed immediately; failure to do so will greatly compound the cost and complexity of later remedial efforts, with environmental degradation beginning even now to pose a major threat to human well-being, especially among the poor.
\end{abstract}

Keywords: Drifting sand, '3S' technologies, WEQ, Basrah Province, Iraq.

\section{Introduction}

Degradation caused by wind erosion is one of the main global environmental problems. It has resulted in deteriorating environments and poor economies, as well as posed a threat to the survival of mankind's entire environment. Its damages have been found in one sixth of the global population, and two third of the countries/regions in the world with an annual direct economic loss of up to US\$ 42.3 billion. This fact has called international communities to pay wide concern and close attention to the land degradation problem (Gomes et al., 2003; Okin, 2005; Jabbar \& Zhou, 2011). Iraq like many other countries in the arid and semi-arid region is exposed to drifting sand risk problems, especially in the 
Middle and Southern parts of the Iraq, which are estimated to be about one million hectares (Al-Farrajii, 1998; Al-Ameri \& Jassim, 2011; Awadh et al., 2011). This problem started because of the problem negligibility which is now expected to have more than $90 \%$ of the cultivable lands (Dougramedji, 1999). Some of the main causes of drifting sand in Iraq are the overgrazing, misuse of the plant coverage, and sand dune formation. Degradation involves multiple causes, and it proceeds at varying rates in different climates (AlFarrajii, 1998). The movable sand dunes have direct effect on the infrastructure such as highways, railways, irrigation canals, agricultural soils, soil erosion, sand storms, as well as the direct negative effect on the environment and human health (Al Janabi et al., 1988). Drifting sand also affects plant growth, especially forages and rangelands that is considered one of the most crucial problems facing animal production in Iraq (Naqash \& Shaker, 1986; Salman \& Saadallah, 1986). The continuous use of unsustainable practices, damage of the infrastructure during the War, and poor maintenance worsened by sanctions, has caused a further soil and plant deterioration.

$$
E=f(I \times K \times C \times L \times V)
$$

Where $\mathrm{E}$ is the potential annual soil loss in (ton hectare year $^{-1}$ ); $\mathrm{f}$ is an indication that the equation includes functional relationships that are not straight-line mathematical calculations; I is the soil erodibility (t. ha $\mathrm{ha}^{-1}$ ); $\mathrm{K}$ is soil ridge roughness factor; $\mathrm{C}$ is the climatic factor; $\mathrm{L}$ is the unsheltered distance (in $\mathrm{m}$ ) along the prevailing wind direction; and $\mathrm{V}$ is the vegetation cover factor (Hagen, 1991; Panebianco \& Buschiazzo, 2008; Zhang et al., 2014). The main objective of the present study was to explore an approach based on LUCC to quickly evaluate and map
Recent estimates showed that $75 \%$ of the total land in Iraq was arid and semi-arid regions and $50 \%$ of this land are subject to wind erosion particularly in the south western part of the Iraq, where land degradation becomes a serious problem (Dougramedji, 1999). There is a lack of information on soil wind erosion, and its effects on soil and land (Lal, 2001; Jabbar \& Xiaoling, 2006). Nickling (1988) reported that wind erosion plays an important role in sand dunes formation and their movement. Abdulla (1990) pointed out that presence of sand dunes in the central and southern parts of Iraq is a result of a sever effect of wind erosion on barren waterless land, particularly, in the dry period of the year. Sand dunes are common in Iraq and they cover about 112 and 200 ha in lower Mesopotamian plain in central and southern parts of the country (Abdulla, 1990). This investigation was conducted to estimate the amount of potential annual soil loss, and its advance, during a long dry period, in most affected area of Iraq. The Wind Erosion Equation (WEQ) developed by Woodruff \& Siddoway (1965) is the most frequently used empirical soil erosion model worldwide. The WEQ is written as

monitoring the drifting sand risks, using $3 \mathrm{~S}$ technology, change detection techniques, and WEQ model. Indeed, the emerging field of degradation assessment draws heavily from these three streams. The novelty of the present work is not so much the development of new conceptual domains, but rather integration across these three traditions.

\section{Materials \& Methods}

\section{Materials}

Study Area: The study region selected was Basrah Province, Iraq (Fig. 1), representing a 
total area of $19.070 \mathrm{~km}^{2}$ between longitude $46^{\circ} 60^{\prime}$ to $48^{\circ} 60^{\prime} \mathrm{E}$ and latitude $29^{\circ} 13^{\prime}$ to $31^{\circ}$ $29^{\prime} \mathrm{N}$. The predominant soil of Iraq is considered sedimentary, especially in central and southern parts of the country. Basrah Province is situated in a desert-type environmental zone with a monsoon climate; summers are very hot, especially July and August, with a mean temperature of $37.4^{\circ} \mathrm{C}$ and a maximum temperature of $45^{\circ} \mathrm{C}$. The average potential evapotranspiration exceeds $2450 \mathrm{~mm} /$ year, while average annual rainfall is less than $100 \mathrm{~mm} /$ year (Jabbar \& Zhou 2011).
Spatial Database Using GIS and Remote Sensing: A multi-temporal Landsat (WRS2: $165 / 39,166 / 38,166 / 39$ and 166/40, dated March 2003 and 2016) image dataset covering the study area was assembled and analysed for land use/cover change as part of soil degradation indicator analysis. The spatial resolution of one pixel of the TM and ETM images was $28.5 \mathrm{~m}$ by $28.5 \mathrm{~m}$. A county-level topographic map, geological map, soil map, meteorological data and all thematic layers were generated in a GIS environment at a scale of 1:250 000 .

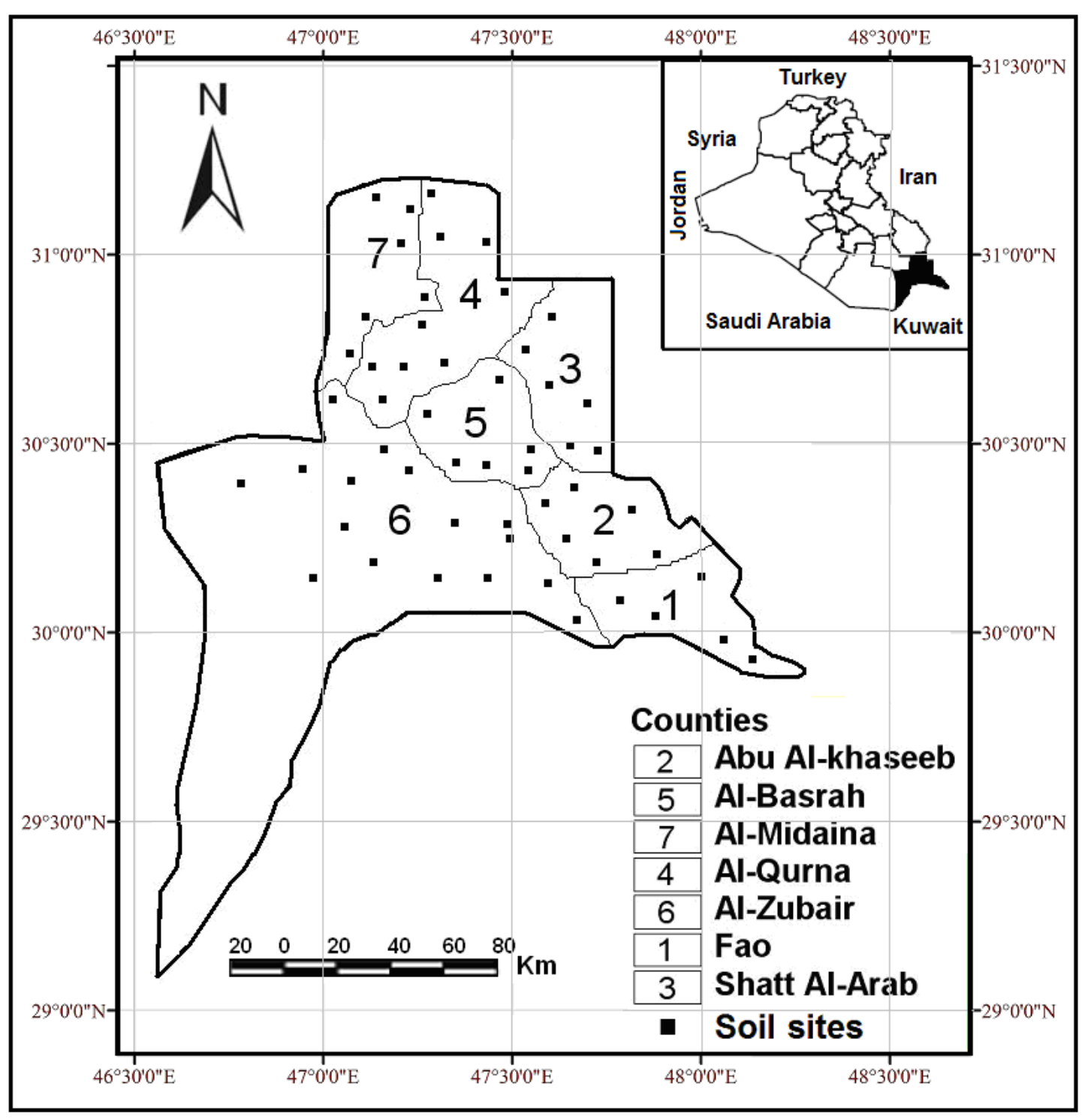

Fig. (1): General location of study area showing counties boundary and soil sites. 
The software packages employed in the present study were ERDAS (image processing), Arc/GIS (analysis and presentation of results) and SPSS (statistical analysis).

\section{Methods}

\section{Image processing and field survey}

Image processing included geometric correction in which ground control points were chosen, referencing a topographic map of scale 1:250 000. The land use/cover characteristics of the study area were classified into 5 categories: vegetable plots, sand, urban/residential land, water bodies and unused land (bare land) (Julien et al. 2011).
Field data were collected in 2003-2004 from a total of 25 plots, comprising 17 evergreen and 8 deciduous vegetation areas (Fig. 1). Selected physical and chemical properties of the soils were listed in Table (1). These properties were measured according to the procedures of Black et al. (1965). The basic size of the plots was $15 \times 15 \mathrm{~m}$, established, subject to area conditions, using a Global Positioning System (GPS) receiver set into WGS84 at zone NUTM38 and later transferred to GIS and projected to the datum used for the satellite images (Jabbar et al. 2006).

Table (1): Some physical and chemical properties of soil type and their average value in study area.

\begin{tabular}{lccccccc}
\hline $\begin{array}{c}\text { Physical and } \\
\text { Chemical }\end{array}$ & $\begin{array}{c}\text { Khaseeb } \\
(2) / 1,152\end{array}$ & $\begin{array}{c}\text { Midaina } \\
(7) / 989\end{array}$ & $\begin{array}{c}\text { Qurna } \\
(4) / 2,612\end{array}$ & $\begin{array}{c}\text { Zubair } \\
(6) / 11,618\end{array}$ & $\begin{array}{c}\text { Basrah } \\
(5) / 1,085\end{array}$ & $\begin{array}{c}\text { Fao } \\
(1) / 98\end{array}$ & $\begin{array}{c}\text { Shatt Al-A. } \\
(3) / 1,516\end{array}$ \\
\hline Sand $\left(\mathrm{g} \mathrm{Kg}^{-1}\right)$ & 245.0 & 133.1 & 240.0 & 930.9 & 255.4 & 123.0 & 161.1 \\
\hline Silt $\left(\mathrm{g} \mathrm{Kg}^{-1}\right)$ & 483.6 & 394.4 & 489.6 & 10.2 & 463.5 & 486.6 & 541.2 \\
\hline Clay $\left(\mathrm{g} \mathrm{Kg}^{-1}\right)$ & 271.4 & 472.5 & 270.4 & 40.8 & 281.1 & 390.4 & 297.7 \\
\hline Texture & $\begin{array}{c}\text { Silty } \\
\text { L* }\end{array}$ & $\begin{array}{c}\text { Silty } \\
\text { clay }\end{array}$ & Silty L. & Sandy & Silty L*. & Silty clay & Silty L*. \\
\hline$>0.50 \% * 1$ & 60.60 & 61.5 & 60.60 & 0.20 & 62.40 & 69.5 & 64.75 \\
\hline $0.5-0.25 \% * 1$ & 10.30 & 9.45 & 10.30 & 8.02 & 8.40 & 5.45 & 6.44 \\
\hline $0.25-0.10 \% * 1$ & 8.25 & 7.28 & 8.25 & 61.23 & 7.35 & 4.28 & 7.11 \\
\hline$<0.10 \% * 1$ & 2.29 & 3.16 & 2.29 & 21.58 & 3.29 & 2.16 & 3.15 \\
\hline$(\mathrm{mm}) * 2$ & 0.18 & 0.17 & 0.20 & 0.28 & 0.22 & 0.21 & 0.19 \\
\hline Bulk D. $\left(\mathrm{gcm}^{-3}\right)$ & 1.21 & 1.23 & 1.22 & 1.68 & 1.41 & 1.23 & 1.25 \\
\hline $\mathrm{pH}$ & 7.87 & 7.95 & 7.82 & 7.84 & 7.85 & 8.90 & 7.80 \\
\hline $\mathrm{O} . \mathrm{M}\left(\mathrm{g} \mathrm{Kg}^{-1}\right)$ & 3.70 & 3.10 & 3.75 & 0.19 & 2.60 & 3.20 & 3.73 \\
\hline $\mathrm{EC} \mathrm{dsm}$ & 4.50 & 4.30 & 3.90 & 3.80 & 4.80 & 5.60 & 4.40 \\
\hline $\mathrm{CaCO}\left(\mathrm{g} \mathrm{Kg}^{-1}\right)$ & 120.2 & 130.5 & 118.9 & 169.5 & 118.9 & 125.5 & 124.1 \\
\hline$(\mathrm{cm}) * 3$ & $5-20$ & $2-15$ & $2-15$ & $20-50$ & $10-30$ & $2-15$ & $3-20$ \\
\hline
\end{tabular}

Determining WEQ factor values:

Derivation of the factors required by the WEQ is well documented in the literatures (Cole et al., 1983; Hagen, 1991; Panebianco \& Buschiazzo, 2008). However, recent advancements in GIS technology have enabled more accurate estimation of some EQ factors (Fig. 2). Values assigned to the WEQ factors are discussed below:

Technology soil erodibility factor (I) (t. ha ${ }^{1}$ ): Soil texture triangle (USDA, 1951) can be used with Soil Wind Erodibility Groups 
Jabbar et al ./ Basrah J. Agric. Sci., 33(1): 1-16, 2020

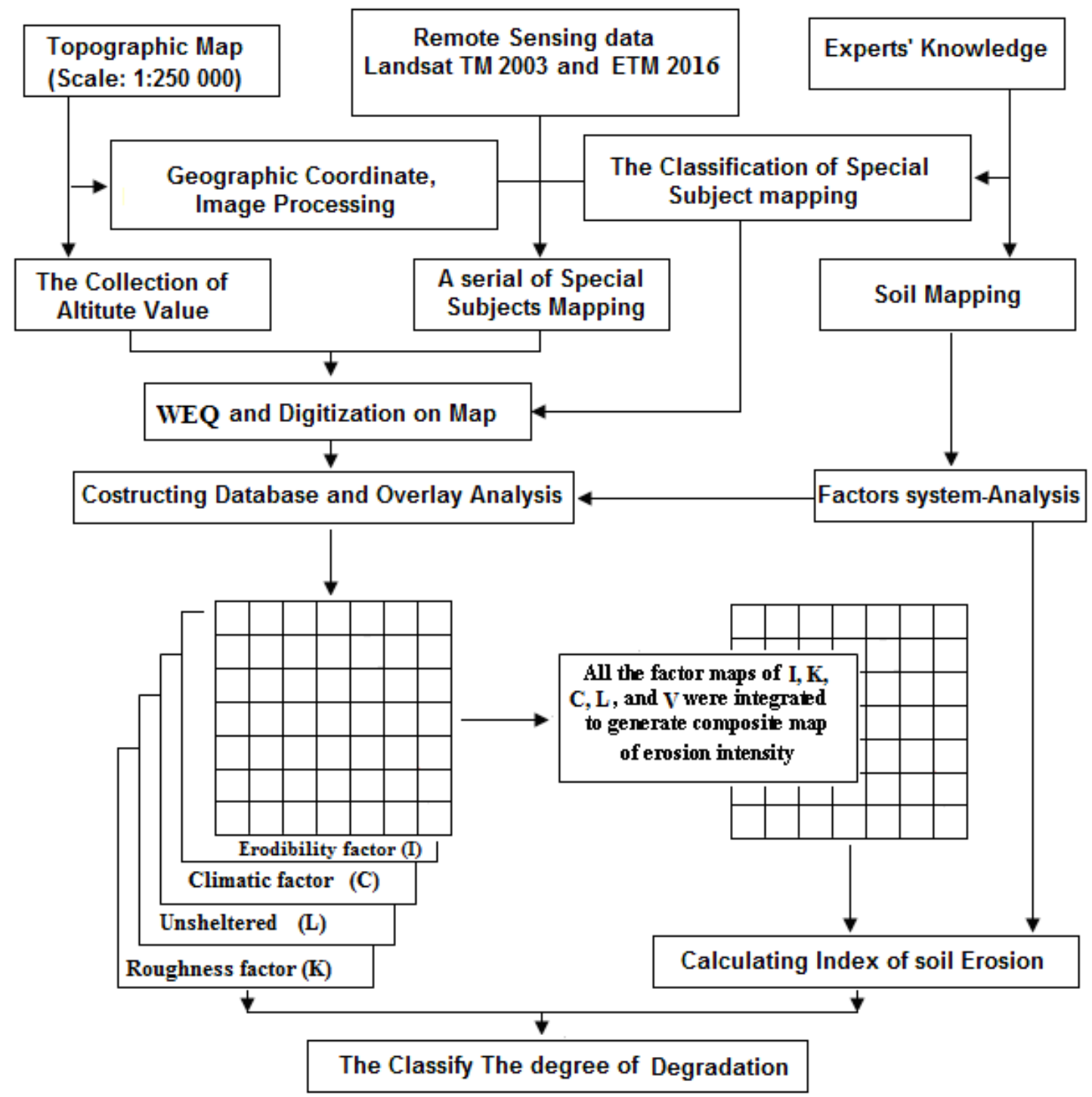

Fig. (2): The Chart of soil degradation assessment using Geo-information.

Table (2): Soil Wind Erodibility Groups (WEG) as related to soil textural.

\begin{tabular}{|c|l|c|c|c|}
\hline WEQ & \multicolumn{1}{|c|}{ Predominant Soil Textural Class } & $\begin{array}{c}\text { Dry } \\
\text { Aggregates } \\
\mathbf{7 0 . 8 4}(\mathbf{\%})\end{array}$ & $\begin{array}{c}\text { Soil } \\
\text { Erodibility } \\
\text { "I" } \\
(\mathbf{M g} / \mathbf{h a} / \mathbf{y r})\end{array}$ & $\begin{array}{c}\text { Soil Ridge } \\
\text { Roughnnes } \\
\text { s Factor } \\
\text { "K" }\end{array}$ \\
\hline $\mathbf{1}$ & Very fine, fine \& medium sands; dune sands & 1 & 695 & 1.0 \\
\hline $\mathbf{2}$ & Loamy sands; loamy fine sands & 10 & 300 & 1.0 \\
\hline $\mathbf{3}$ & Very fine sandy lomas; fine sandy loams; & 25 & 193 & 1.0 \\
\hline $\mathbf{4}$ & $\begin{array}{l}\text { Clays; silty clays, noncalcareous clay loams and silty } \\
\text { clay loams with >35\% clay }\end{array}$ & 25 & 193 & 0.75 \\
\hline $\mathbf{4 L}$ & $\begin{array}{l}\text { Calcareous loams \& silt loams; calcareous clay } \\
\text { loams \& silty clay loams with <35\% clay content }\end{array}$ & 25 & 193 & 0.75 \\
\hline $\mathbf{5}$ & $\begin{array}{l}\text { noncalcareous loams \& silt loams with < 20\% clay } \\
\text { content; sandy clay loams; sandy clay }\end{array}$ & 40 & 193 & 0.75 \\
\hline $\mathbf{6}$ & $\begin{array}{l}\text { noncalcareous loams \& silt loams with > 20\% } \\
\text { clay; noncalcareous clay loams with <35\% clay }\end{array}$ & 45 & 126 & 0.75 \\
\hline $\mathbf{7}$ & Silts; noncalcareous silty clay loams with <35\% clay & 50 & 108 & 0.50 \\
\hline $\mathbf{8}$ & $\begin{array}{l}\text { Very wet or stony; usually not subject to wind } \\
\text { erosion }\end{array}$ & - & - & - \\
\hline
\end{tabular}


(SWEG) (Table 2) (Woodruff \& Siddoway, 1965; Wu 2003;) to obtain general (I) values.

2- Climatic factor C (\%) for the study period (FAO, 1979; Skidmore, 1986),

$$
C(\%)=1 / 100 \sum U^{3}(E T P i-P i / E T P i) d
$$

Where (U) is the local wind velocity ( $\mathrm{m} \mathrm{s}^{-}$ ${ }^{1}$ ), (d) is the number of days in the month,

(Pi) Rainfall (mm) and (ETPi) evaporation $(\mathrm{mm})$

Climatic factor $\mathrm{C}$ values were calculated from the climatic measurements (wind velocity), and the resulted values were $0.05-0.95$.

$$
\begin{gathered}
\text { if } \mathrm{R} \text { is }<0.57 \text {, then } \mathrm{K}=1.0 \\
\text { if } 0.57<\mathrm{R}<22.3 \text {, then } \mathrm{K}=0.913-0.153 \ln (\mathrm{R}) \\
\text { if } \mathrm{R} \geq 22.3 \text {, then } \mathrm{K}=0.336 \mathrm{e}^{(0.013 \mathrm{R})} \\
\text { Where, } R=H^{2} / \mathrm{S}
\end{gathered}
$$

$\mathrm{H}$ is ridge height $(\mathrm{mm})$, and $\mathrm{S}$ is ridge distance (mm).

The surface ridge height of the studied fields was taken as 1 where the roughness of soil surface was smooth (sand dunes), while it was taken as 0.7 at other sites where there were fields of croplands or grasslands.

4- Unsheltered distance (L factor): Distance across field (Df) is the total distance across a given field measured along the prevailing wind erosion direction (Fig. 3). On an

$$
D F=L w(L \cos A+w \sin A)^{-1}
$$

unprotected, eroding field the rate of soil flow is zero on the windward edge and increases with distance to leeward until, if the field is large enough, the flow reaches a maximum that a wind of a particular velocity can sustain. The distance required for soil flow to reach this maximum on a given soil is the same for any erosive winds. It varies only and inversely with the erodibility of a field surface. It can be computed from the length and width of the field if the prevailing wind erosion direction is known (Skidmore, 1988):

Where, $\mathrm{L}$ is the length of field (m), w is the width of field (m), and A is the angle between side $\mathrm{w}$ and the prevailing wind direction.

In this study, the length of the studied field was $200-300 \mathrm{~m}$ and the width was $50-75 \mathrm{~m}$,

$$
V=a X^{b}
$$

while the angle between side $\mathrm{w}$ and prevailing wind direction (NW-SE) was 45 degrees.

5- Vegetation Factor (V): Information for different crops has been rendered in

the form of a power equation (Woodruff \& Siddoway, 1965; Potter, 2016): 


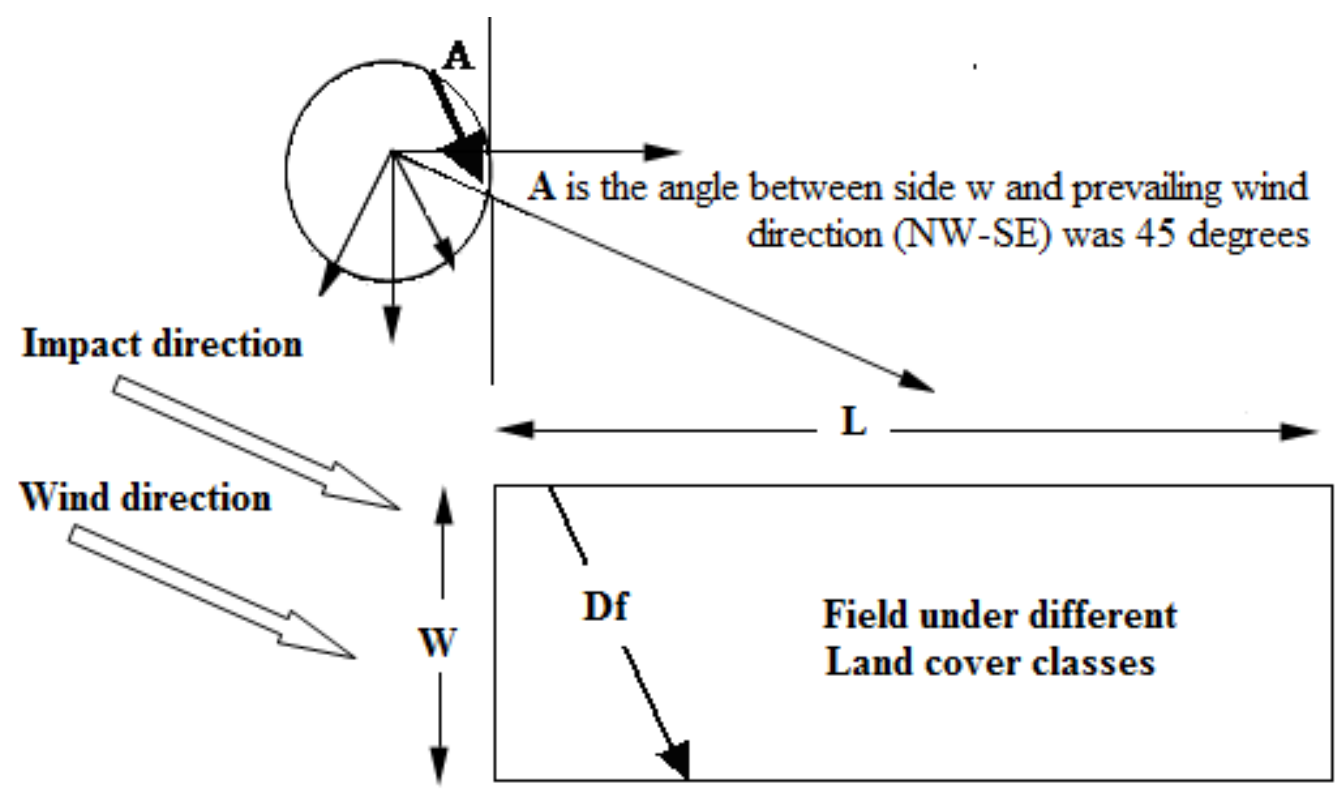

Fig. (3): Total distance across a given field measured along the prevailing wind erosion direction.

Where, $\mathrm{V}$ is the equivalent vegetative cover $\left(\mathrm{kg} \mathrm{ha}^{-1}\right), \mathrm{X}$ is the quantity of vegetation $(\mathrm{kg}$ $\mathrm{ha}^{-1}$ ) to be converted to the standard 'small grain equivalent' residue, and $a$ and $b$ are constants, dependent upon crop type.

The vegetation status was estimated during the fieldwork for the 140 studied sites in the southern parts of Iraq.

Based online at (http://homepage.boku.ac.at/h9340509/weoc/) and Skidmore (1988) were used to solve the variables of the wind erosion equation. In this study the WEQ worksheet model was applied to estimate the wind erosion potential for the study areas.

\subsubsection{Assessment of affected areas}

This part of the research aims to differentiate the sand-affected area from non-sand-affected

$$
N D V I=(N I R-R) /(N I R+R)
$$

Where, $\mathrm{R}$ and NIR are the red and near infrared bands.

areas using various methods of digital image classification and band match methods (Potter, 2016). To reach that objective, land use was classified using both unsupervised and supervised techniques applied to the Landsat TM 2003 and Landsat ETM 2016 data coupled with ground truth investigation to verify the percentage of classification accuracy and to investigate the topographic and other related characteristics of the sandaffected area and those of non-sand-affected area. After getting the potential and/or sandaffected areas from image classification, different remote sensing indicators such as the Normalized Vegetation Index (NDVI) (Purevdorj et al., 1998) and the Topsoil Grain Size Index (GSI) (Xiao et al., 2006) were employed to study how these indices work for sand-affected areas in the study area. 


$$
\mathrm{GSI}=(\mathrm{R}-\mathrm{B}) /(\mathrm{R}+\mathrm{B}+\mathrm{G})
$$

Where, $\mathrm{R}, \mathrm{B}$, and $\mathrm{G}$ are the red, blue, and green bands of the remote sensing data. GSI value is close to 0 in vegetated area, and for water body, it is negative value.

\section{Results \& Discussion}

\section{Classification of wind erosion magnitudes}

Soil wind erosion assessment was carried out for the different land cover classes in seven counties in the Basrah province. The chosen approach for soil erosion assessment by wind with WEQ linked to a GIS enables the designation of potential risk areas. The results in the Table 3 show that the average potential annual wind erosion rates for the year 2003 for the Al-Zubair County were 203.2, 50.1, 31.5, and 20.7 Mg ha-1 $\mathrm{yr}^{-1}$ for the bare lands, sparse vegetation lands, grasslands, and croplands fields at the study area, respectively. According to the classification of wind erosion magnitude (Zachar, 1982; Xiao et al., 2015;), the average seven bare lands fields located belong to the catastrophic to slight grade. The results showed in 2016 there was a big increase in the annual soil loss by wind in the bare lands fields while there was a decrease in the annual soil loss in the cropland fields. The main reason for the decline of the annual soil loss by wind was the vegetation cover ( $\mathrm{V}$ factor). The increase in the amount of the vegetation cover over the studied areas reduced the annual soil loss. Further examination of table (3) the total soil loss $(\mathrm{Y})$ is related to dry soil aggregate $>0.84$ $\mathrm{mm}$ of soil (X), this relation indicated that the soil erosion decreases with increases dry soil aggregate $>0.84 \mathrm{~mm} \%$. Statistical analysis of the results indicated that there was a correlation coefficient equal to $(r=-0.84)$. This indicates a strong relationship between the studied variables, as well as a statistically significant relationship between the potential annual wind erosion rates and the percentage of dry non-erodible surface soil aggregates larger than $0.84 \mathrm{~mm}$ in diameter, resulted in the vegetation degeneracy and land degradation and as a result of the Gulf War (1990-1991), the war machinery and the complex systems of ground fortifications have affected southern parts of Iraq desert surface intensively. Consequently, several elements of the desert ecosystem have been severely damaged. These include the following papers presented at 1st Conference on Environmental Consequences of War, held in Washington, DC, in 1998: (a) degradation of vegetation cover; (b) soil disturbance; (c) exposure and desegregation of near surface sediments; (d) landscape disruption; (e) soil compaction, and (f) pollution by oil and explosives (Howle, 1998; Omar et al., 2005).

\section{Drifting sand risk monitoring}

The aim of this research was to identify how the different remote sensing indices: Normalized Differential vegetation Index (NDVI) and the Topsoil Grain Size Index (GSI) work for sand-affected land delineation in this study area. Results from the indices analysis of the Landsat TM 2003 and Landsat ETM 2016 data showed that the indices that gave acceptable satisfactory results in distinguishing sand area from non-sand area were NDVI and GSI. The obtained data reveals that the change detection, area of active sand movement has increased from $4118.3 \mathrm{~km}^{2}$ to $4558.1 \mathrm{~km}^{2}$ and the highly sensitive areas for drifting sand is located in the western south parts of the Basrah Province (Table 4). This result showed potentially high-risk land degradation for further investigation. Results also suggested that enhancements to this method could help 
Jabbar et al ./ Basrah J. Agric. Sci., 33(1): 1-16, 2020

Table (3): Annual soil loss percentages of the studied sites in the southern part of Iraq.

\begin{tabular}{|c|c|c|c|c|c|c|c|}
\hline \multirow[t]{2}{*}{ Locality } & \multirow[t]{2}{*}{$\begin{array}{l}\text { Land cover } \\
\text { classes }\end{array}$} & \multirow[t]{2}{*}{ Soil Texture } & \multirow[t]{2}{*}{$\begin{array}{l}\text { Aggregate } \\
>84 \mathrm{~mm} \mathrm{\%}\end{array}$} & \multicolumn{2}{|c|}{$\begin{array}{l}\text { Annual Soil loss (Mg. } \\
\left.\qquad \mathrm{ha}^{-1} \mathrm{yr}^{-1}\right)\end{array}$} & \multicolumn{2}{|c|}{$\begin{array}{l}\text { Wind Erosion } \\
\text { Grade** }\end{array}$} \\
\hline & & & & 2003 & 2016 & 2003 & 2016 \\
\hline \multirow[t]{4}{*}{ Abu Al-Khaseeb } & Bare lands & Silty L.* & 35.56 & 4.59 & 5.78 & Slight & Moderate \\
\hline & Sparse veg. & Silty L.* & 35.20 & 4.54 & 4.90 & Slight & Slight \\
\hline & Grasslands & Silty L.* & 37.85 & 4.48 & 4.67 & Slight & Slight \\
\hline & Croplands & Silty L.* & 38.93 & 4.48 & 4.15 & Slight & Slight \\
\hline \multirow[t]{4}{*}{ Al- Midaina } & Bare lands & Silty clay & 44.74 & 0.82 & 1.23 & Slight & Slight \\
\hline & Sparse veg. & Silty clay & 44.78 & 0.74 & 1.19 & Slight & Slight \\
\hline & grasslands & Silty clay & 44.80 & 0.70 & 1.15 & Slight & Slight \\
\hline & Croplands & Silty clay & 44.91 & 0.70 & 0.43 & Slight & Slight \\
\hline \multirow[t]{4}{*}{ Al-Qurna } & Bare lands & Silty L.* & 35.56 & 0.89 & 1.35 & Slight & Slight \\
\hline & Sparse veg. & Silty L.* & 35.20 & 0.84 & 1.28 & Slight & Slight \\
\hline & grasslands & Silty L.* & 35.64 & 0.75 & 1.28 & Slight & Slight \\
\hline & Croplands & Silty L.* & 35.65 & 0.75 & 1033 & Slight & Slight \\
\hline \multirow[t]{4}{*}{ Al-Zubair } & Bare lands & Fine $S$. & 0.95 & 153.21 & 203.21 & V. severe & Catastrophic \\
\hline & Sparse veg. & Sandy & 10.15 & 39.99 & 50.18 & Severe & Very severe \\
\hline & Grasslands & Sandy & 16.35 & 24.77 & 31.56 & Severe & Severe \\
\hline & Croplands & Sandy & 24.82 & 20.89 & 20.73 & Severe & Severe \\
\hline \multirow[t]{4}{*}{ Basrah } & Bare lands & Silty L.* & 32.66 & 2.59 & 2.78 & Slight & Slight \\
\hline & Sparse veg. & Silty L.* & 32.25 & 2.14 & 2.20 & Slight & Slight \\
\hline & Grasslands & Silty L.* & 32.29 & 2.10 & 2.15 & Slight & Slight \\
\hline & Croplands & Silty L.* & 32.29 & 2.10 & 1.95 & Slight & Slight \\
\hline \multirow[t]{4}{*}{ Fao } & Bare lands & Silty clay & 43.26 & 1.42 & 1.73 & Slight & Moderate \\
\hline & Sparse veg. & Silty clay & 43.20 & 1.34 & 1.30 & Slight & Slight \\
\hline & Grasslands & Silty clay & 43.25 & 1.34 & 1.29 & Slight & Slight \\
\hline & Croplands & Silty clay & 43.29 & 1.28 & 0.97 & Slight & Slight \\
\hline \multirow[t]{4}{*}{ Shatt Al-Arab } & Bare lands & Silty L.* & 35.56 & 4.64 & 5.12 & Slight & Moderate \\
\hline & Sparse veg. & Silty L.* & 35.20 & 3.55 & 3.78 & Slight & Slight \\
\hline & Grasslands & Silty L.* & 37.9 & 2.67 & 2.95 & Slight & Slight \\
\hline & Croplands & Silty L.* & 44.9 & 1.86 & 1.54 & Slight & Slight \\
\hline
\end{tabular}


monitor the condition, and extent, of sand cover areas on the margins of vegetation areas. The entire area was presumed to be subject to vegetation degradation, mainly by climatic variation and anthropogenic activities. Thus, $24.1 \%$ of the land area had vegetation cover in 2016 , while $26.8 \%$ had vegetation cover in 2003 revealing the gravity of vegetation cover change problem in this study area. The declining vegetation was conspicuous in 2016 and larger than that in 2003 in the Al-Zubair County areas.

Table (4): Drifting sand coverage percentages and its increasing rates in the study area derived from GSI.

\begin{tabular}{|c|c|c|c|c|c|c|c|c|}
\hline \multirow[t]{2}{*}{ Study site } & \multirow[t]{2}{*}{$\begin{array}{l}\text { Area } \\
\left(\mathrm{km}^{2}\right)\end{array}$} & \multicolumn{2}{|c|}{$\begin{array}{c}\text { Drifting Sand } \\
2003\end{array}$} & \multicolumn{2}{|c|}{$\begin{array}{c}\text { Drifting Sand } \\
2016 \\
\end{array}$} & \multicolumn{2}{|c|}{$\begin{array}{c}\text { Drifting Sand } \\
2003 \sim 2016 \\
\end{array}$} & \multirow{2}{*}{$\begin{array}{c}\text { Drifting } \\
\text { Sand Rate } \\
\mathrm{km}^{2} . \mathrm{yr}^{-1}\end{array}$} \\
\hline & & $\left(\mathrm{km}^{2}\right)$ & $(\%)$ & $\left(\mathrm{km}^{2}\right)$ & $(\%)$ & $\left(\mathrm{km}^{2}\right)$ & $(\%)$ & \\
\hline Abu Al-Khaseeb & 1,151 & 190.1 & 16.5 & 196.8 & 17.1 & 6.8 & 3.5 & 0.51 \\
\hline Al Midaina & 989 & 22.7 & 2.3 & 23.7 & 2.4 & 1.0 & 4.4 & 0.07 \\
\hline Al-Qurna & 2,611 & 88.8 & 3.4 & 91.4 & 3.5 & 2.6 & 2.9 & 0.20 \\
\hline Al-Zubair & 11,619 & 3732.6 & 32.2 & 4152.8 & 35.7 & 420.1 & 11.2 & 32.31 \\
\hline Basrah & 1,086 & 49.9 & 4.6 & 55.4 & 5.1 & 5.5 & 11.0 & 0.43 \\
\hline Fao & 98 & 10.8 & 11.1 & 11.9 & 12.2 & 1.1 & 10.1 & 0.08 \\
\hline Shatt Al-Arab & 1,516 & 24.2 & 1.6 & 25.7 & 1.7 & 1.5 & 6.1 & 0.34 \\
\hline Total & 19,070 & 4119.1 & 21.6 & 4557.7 & 23.9 & 438.6 & 10.6 & \\
\hline
\end{tabular}

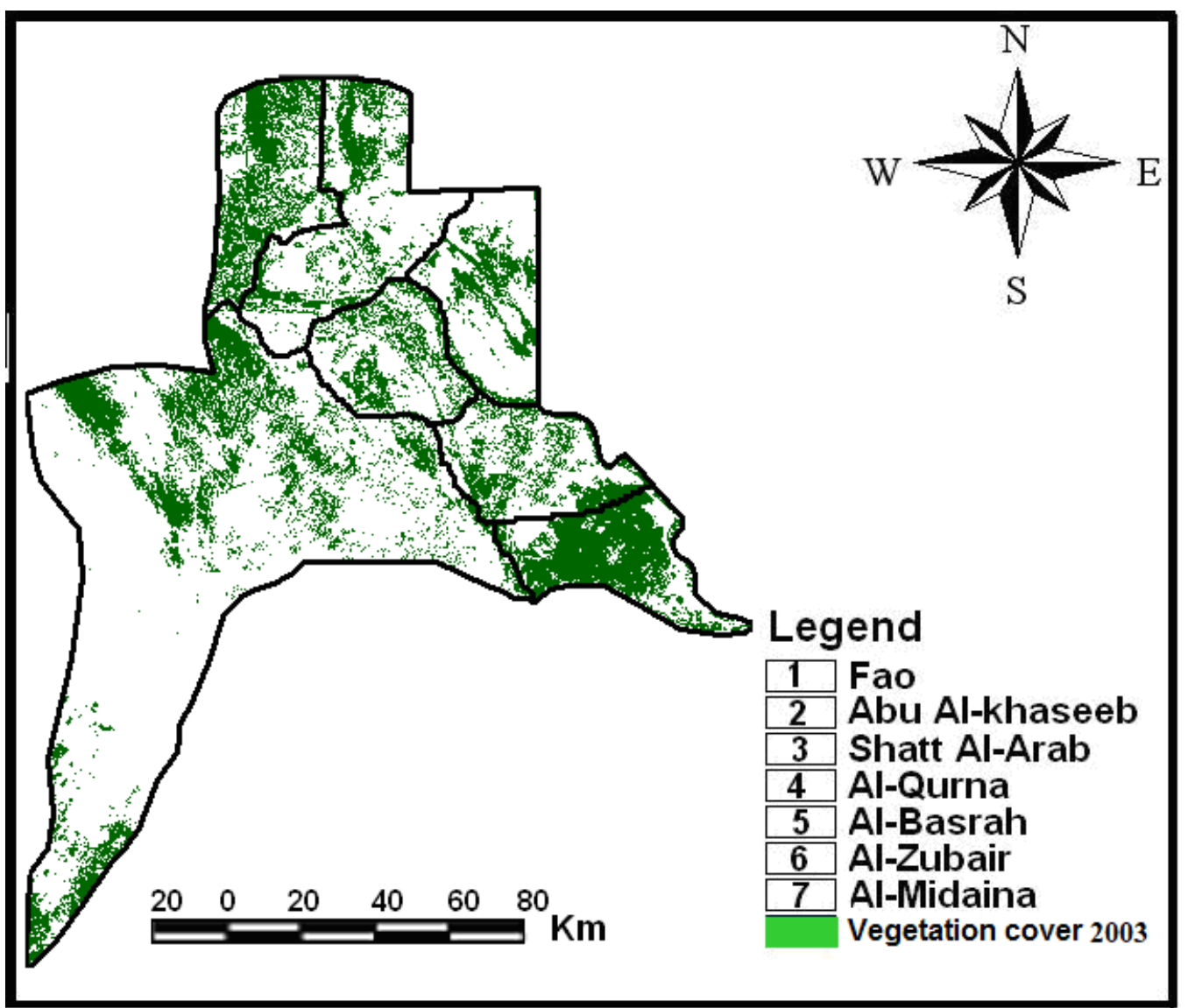

Fig. (4): Vegetation cover of Basrah Province in 2003 derived from NDVI. 


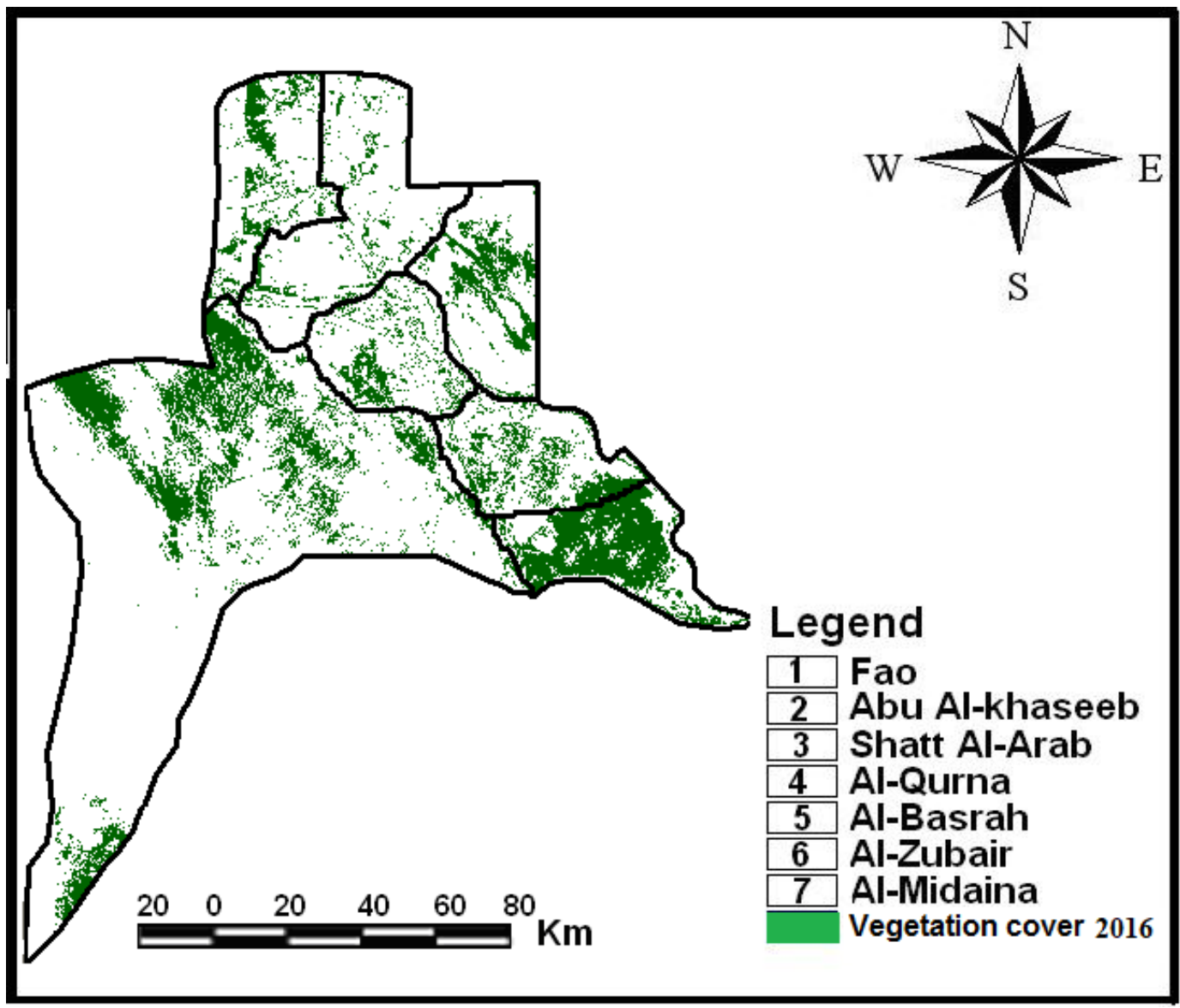

Fig. (5): Vegetation cover of Basrah Province in 2016 derived from NDVI.
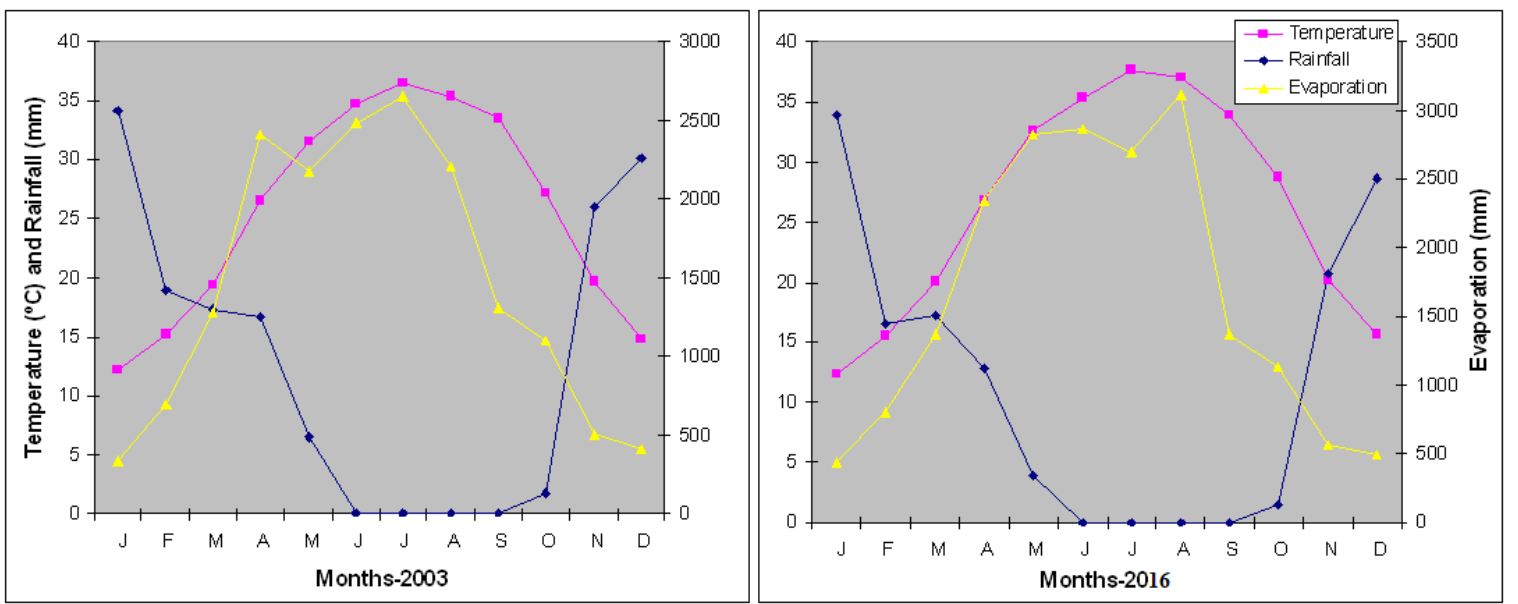

Fig. (6): Monthly Precipitation, potential evapotranspiration and temperature in Basrah for the year 2003 and 2016.

However, extended land degradation was clearly found in the study location (Fig. 4 and Fig. 5). The results of the statistical analysis showed that sand area has a significant correlation with vegetation cover negative change (0.92). The arid environment of the study area is characterized by low precipitation and high evapotranspiration (Fig. 6). According to statistics of soil sandy thematic map, the total study area is $19,070 \mathrm{~km}^{2}$, it represents $61.9 \%$ of the area belongs to severe class. The moderate 
sensitive areas for drifting sand exhibit the rest of the southern parts of the study location as it represents $18.9 \%$ of the total area. The northern parts of the study location are characterized by a very low and low sensitivity for drifting sand as they represent 8.5 and $10.7 \%$ of the total area respectively (Table 5). It is supposed that the whole area is subject to land degradation, as we mentioned previously, mainly by anthropogenic activities and climatic variation, clearly, these results show the indication of desertification by soil wind erosion in the Basrah Province (Table 5). Climate changes (mainly the rising of temperature $\left(37.4^{\circ} \mathrm{C}\right)$, low rainfall (less than $100 \mathrm{~mm} /$ year $)$, and wind speed $\left.\left(30 \mathrm{~ms}^{-1}\right)\right)$ not only soil wind erosion and intensified surface water evaporation, but also caused the wetland decrease, sand dune movement, and vegetation degradation. Anthropogenic causes (mainly the government policy on land use led to extensive changes in land cover and irrational grazing). Howle (1998) assessed the Gulf-War-related soil degradation forms and concluded that soil compaction resulted in the reduction of the soil infiltration capacity by at least 50 per cent. Al-Awadhi \& Misak (2001) discussed the causes, indicators, and longterm consequences of land degradation in the northwestern corner of the Arabian Gulf.
Their study indicated that at least 70 per cent of the desert ecosystem of the northwestern corner of the Arabian Gulf suffers some degree of land degradation. A search of the literature revealed that the soil degradation is a most significant form of land degradation in Basrah area and it increases the rate of vegetation degradation processes (e.g. Shahid et al., 1999; Al-Dousari et al., 2000; AlAwadhi \& Misak, 2001). All these reasons result in the changes of surface, which lead the regional land degradation. Soil wind erosion is a global environmental hazard, and also a severe Iraqi environmental problem. It adversely affects crop yields and agricultural production in sand affected farm lands. Erosion also affects water quality (rivers, streams and lakes), and the structure integrity of buildings, roads and other infrastructures. Furthermore, ecosystems such as wetlands and forests are being degraded by increasing erosion problems. As a result, agricultural production from farming industries such as grazing and cropping is diminished. Obviously, monitoring and managing erosion is one of the greatest natural resource management challenges in national, state and regional levels.

Table (5): The categories of drifting sand and the proportion of each category.

\begin{tabular}{lcc} 
Class & Area $\left(\mathbf{k m}^{\mathbf{2}}\right)$ & $\mathbf{\%}$ \\
\hline Very low drifting sand areas & 1620.9 & 8.5 \\
\hline Low drifting sand areas & 2040.5 & 10.7 \\
\hline Moderately drifting sand areas & 3604.2 & 18.9 \\
\hline Sever drifting sand areas & 6445.6 & 33.8 \\
\hline Very sever drifting sand areas & 5358.7 & 28.1 \\
\hline Total & 19,070 & 100
\end{tabular}

\section{Conclusion Remarks}

Results in this study show that the information about drifting sand can be gained and mapped efficiently from the wind soil erosion model and Geo-information data. (WEQ), (NDVI), and (GSI) are powerful models for the qualitative as well as quantitative assessment of land degradation intensity and a good indicator of 
desertification damage. They are important parameters for sandy desertification risk monitoring. Using them, we can determine the indicators for evaluating desertification damages, and establish the RS and GIS information models for sandy desertification monitoring and estimation. This is an effective approach for drifting sand risk monitoring in location study. Areas of 6445.6 and $5358.7 \mathrm{~km}^{-2}$ fall under the severe and very severe priority classes respectively for whole study area. These areas should be prioritized for immediate conservation measures. In accordance with Jabbar (2001) whom indicated to the importance of soil conditioners for the fixation of sand soil in Iraq, and Zhu \& Wang, (1993), who developed a model for rehabilitation of desertified land in which experimental demonstration was combined with popularization processes; successful solutions to the problem require a combination of mechanical, biological, ecological, engineering, and legislative measures. Mechanical measures, such as bundling and deployment of straw grid fences, Clayey blocks barriers, Cane branches barriers, and dry planting of Tamarix (tamarix articulata) cuttings in flat sandy areas, aim at stabilizing mobile sand dunes while biological measures intend to reduce wind velocity by erection of windbreaks (Jabbar, et al., 2002; Jabbar, 2003). Ecological measures include diversification of traditional farming activities including animal husbandry and forestry. A systematic approach would include the establishment of effective vegetation cover composed of forest belts, windbreak networks, and scattered patches of orchards and grassland. Engineering measures such as water conservancy project or watershed development would aim at the improvement of rainwater conservation for facilitating survival and growth of vegetation, thus stabilizing mobile dunes. This study recommended that there is a need to establish a professional arid environment center, which can be coordinated with government sectors and different universities in southern part of Iraq to solve the various environmental problems. It is also necessary to compare the case of Basrah Province with other important cities in other developing countries that are experiencing similar forces of degradation processes. It is hoped that our application of the techniques of remote sensing and GIS to environmental research as demonstrated in this study can open up new arena of comparative research so that a broad and full picture can eventually be unfolded to shed light over the pattern and processes of land use transformation in Iraq under environment degradation processes.

\section{Acknowledgments}

This research was supported by the Basrah University and Department of Geology, Earth Sciences, HCC, Seattle, Washington, USA. The authors are grateful to the anonymous reviewers for their critical review and comments on drafts of this manuscript.

\section{Conflicts of interest}

The authors-declare-that they have no conflict of interests.

\section{References}

Abdulla, H.J. (1990) Rate of sand dune movement during the dry season in the lower Mesopotamian plain. Basrah J. Agric. Sci., 2: 99-107.

Al-Ameri, T.K. \& Jassim S.Y. (2011) Environmental changes in the wetlands of Southern Iraq based on palynological studies. Arab J. Geosci., 4: 443-461 https://doi.org/10.1007/s12517-009-0102-9 
Al-Awadhi, J.M. \& Misak, R. (2001). The causes and consequences of desertification in Kuwait: A case study and a possible rehabilitation plan. Proceeding of the $1^{\text {st }}$ Saudi Sci. Conf., April 9-11. King Fahad Univ. Petroleum Mineralogy: Dhahran; 229-251.

Al-Dousari, A.; Misak, R. \& Shahid, S. (2000). Soil compaction and sealing in Al Salmi area, western Kuwait. Land Deg. Dev., 11: 401-418. https://doi.org/10.1002/1099145X(200009/ 10)11:53.0.CO;2-4

Al-Farrajii, F.A. (1998). Combating desertification in Iraq. Desert Control Bull., 33: 2-10.

Al Janabi, K.Z.; Ali A.J.; Al-Taie A. \& Jack, T.J. (1988). Origin and nature of sand dunes in the alluvial plains of southern Iraq. J. Arid Environ., 14: 27-34.

Awadh S.M.; Ali M.O. \& Ali R.A. (2011) Mineralogy and palynology of the Mesopotamian plain sediments, Central Iraq. Arab J. Geosci., 4: 1261-1271

Black, G. R. (1965). Bulk Density. In: Black, C. A.; Evans D. D. \& White, J L, eds. Methods of Soil Analysis. Part 1. Agron. 9: 379-390.

Cole, G.W.; Lyles, L. \& Hagen, L.J. (1983) A simulation model of daily wind erosion loss. Trans. Am. Soc. Agr. Eng., 26(6): 1758-1765.

https://doi.org/10.13031/2013.33839

Dougramedji J.S. (1999) Aeolian sediment movements in the lower alluvial plain, Iraq. Desert Control Bull., 35: 45-49.

Food and Agriculture Organization (FAO) (1979). A Provisional Methodology for Soil Degradation Assessment. Rome,: 73pp.
Gomes, L.; Arrue, J.L.; Lopez, M.V.; Sterk, G.; Richard, D.; Gracia, R.; Sabre, M.; Gaudichet, A. \& Frangi, J.P. (2003). Wind erosion in a semiarid area of Spain: The WELSONS project. Catena, 52: 235-256. https://doi.org/10.1016/S03418162(03)00016-X

Hagen, L.J. (1991) A wind erosion prediction system to meet user needs. J. Soil Water Conser.,, 46(2): 106-111.

Howle S. (1998). The long term environmental consequences of the Gulf War in northeastern Kuwait. M. Sc. Thesis. Univ. Massachusetts: Boston: 147pp.

Jabbar, M.T. (2001). Soil loss by wind erosion for three different textured soil treated with polyacrylamide and crude oil, Iraq. J China Univ. Geosci, 2: 113-116.

Jabbar, M.T. (2003). Using remote sensing and GIS techniques to study soil degradation processes in North Shaanxi Province, China. J China Univ. Geosci., 4: 356-362.

Jabbar M.T. \& Xiaoling, C. (2006). Land degradation assessment with the aid of geo information techniques. J Earth Surf. Processes Landf., 31: 777-784. https://doi.org/10.1002/esp.1298

Jabbar, M.T.; Guangdao, H. \& Jianguo, C. (2002). Study of sand dunes and their effect on desertification of cultivated lands in Shaanxi Province, China using remote sensing techniques. J. China Univ. Geosci., 3: 234-239.

Jabbar, M.T.; Shi, Z.; Wang, T. \& Cai, C. (2006). Vegetation change prediction with geo-information techniques in the three gorges area of China. Pedosphere, 16(4): 457-467. https://doi.org/10.1016/S10020160(06)60076-3Get rights and content 
Jabbar, M.T. \& Zhou, X. (2011). Ecoenvironmental change detection by using remote sensing and GIS techniques: a case study Basra province, south part of Iraq. Environ. Earth Sci., 64: 1397-1407. https://doi.org/10.1007/s12665-011-0964-5

Julien, Y.; Sobrino, J.A. \& Jiménez-Muñoz, J.C. (2011). Land use classification from multitemporal landsat imagery using the Yearly Land Cover Dynamics (YLCD) method. Int. J. App. Earth Observ. Geoinform., 13: 711-720. https://doi.org/10.1016/j.jag.2011.05.008

Lal, R. (2001). Soil degradation by erosion. Land Degrad. Dev., 12: 519-539. https://doi.org/10.1002/ldr.472

Naqash, A.B. \& Shaker, S.N. (1986). Aeolian sedimentation processes in lower Mesopotamian Plain. J. Water Res., 5(1): 486-508.

Nickling, W.G. (1988). The maltation of particle movement by wind. Sedimentology, 35: 499-511. https://doi.org/10.1111/j.1365-

3091.1988.tb01000.x

Okin. G.S. (2005). Dependence of wind erosion on surface heterogeneity, J. Geophys. Res., $\quad 110 . \quad$ D11208. doi:10.1029/2004JD005288.

Omar SAS, Bhat NR, Shahid SA, Assem A (2005) Land and vegetation degradation in war-affected areas in the Sabah Al-Ahmad nature reserve of Kuwait: a case study of Umm Ar Rimam. J Arid Environ 62:475490.

https://doi.org/10.1016/j.jaridenv.2005.01. 009

Panebianco, J.E., \& Buschiazzo, D.E. (2008). Erosion predictions with the Wind Erosion Equation (WEQ) using different climatic factors. Land Deg. Dev., 19(1): 3644. https://doi.org/10.1002/ldr.813

Potter, C. (2016). Analysis of desert sand dune migration patterns from Landsat image time series for the Southern California Desert. J. Remote Sensing GIS, 5: 1-8. https://doi.org/10.4172/24694134.1000164

Purevdorj, T.S.; Tateishi, R.; Ishiyama, T. \& Honda, Y. (1998). Relationships between percent vegetation cover and vegetation indices. Int. J. Remote Sens., 19(18): 35193535 .

https://doi.org/10.1080/014311698213795

Salman, H.H. \& Saadallah, A.S. (1986). Dust fallout in central and southern Iraq. J. Water Res., 5(1): 599-620.

Shahid, S.A.; Omar, S.A. \& Al Ghawas, S. (1999). Indicators of desertification in Kuwait and their possible management. Desert Control Bull., 34: 261-266.

Skidmore, E.L. (1986).Wind Erosion Climatic Erosivity. Climate Change, 9 195-208.

Skidmore, E.L. (1988). Wind Erosion. 203233. In: Lal, R. (Ed.). Soil Erosion Methods. Soil and Water Conservation Society. 181pp.

USDA (1951). Soil Survey Manual. United States Department of Agriculture, Handbook no. 18, Washington. 603pp. DOI: 10.1002/jpln.19530610213

Woodruff N.P., \& Siddoway, F.H. (1965). A Wind Erosion Equation. Proc. Soil Sci. Soc. Am.,. 29(5): 602-608.

Wu, Z. (2003): Aeolian Landform and Sand Control Engineering. Beijing: Science Press, 261-266.

Xiao, J.; Shen, Y.; Tateishi, R. \& Bayer, W. (2006). Development of topsoil grain size 
index for monitoring desertification in arid land using remote sensing. Int. J. Remote Sens. 27(12):

2411-2422. https://doi.org/10.1080/014311606005543 63

Xiao, J. H.; Qu, J. J.; Yao, Z. Y.; Pang, Y. J.\& Zhang, K. C. (2015): Morphology and formation mechanism of sand shadow dunes on the Qinghai-Tibet Plateau. J.Arid Land, 7: 10-26. https://doi.org/10.1007/s40333014-0074-9

Zachar, D. (1982). Soil Erosion (Development in Soil Science).
Amsterdam, Elsevier Sci. Publ. Company. 547 pp.

https://doi.org/10.1177/030913338500900120

Zhang, S.; Liu, Y. \& Wang, T. (2014): How land use change contributes to reducing soil erosion in the Jialing River Basin, China. Agric. Water Manage., 133: 65-73. https://doi.org/10.1016/j.agwat.2013.10.01 6

Zhu, Z. \& Wang, T. (1993). Trends in desertification and its rehabilitation in China. Desert Control Bull., 22: 27-30.

\section{تقييم زحف الرمال على الاراضي الزراعية في محافظة البصرة باستخدام تقانات الاستثعار عن بعد ونظم المعلومات الجغرافية ونظام تحدبد الموقع \\ مشتاق طالب جبار 1 و اريك مز بير1 وصلاح مهدي سلطان العطب2}

Geology Department, Earth Sciences, HCC/ Seattle, Washington

$$
\begin{aligned}
& \text { 1قسم علم الارض، علوم الارض، سيتل، الو لايات المتحدة الاميريكية }
\end{aligned}
$$

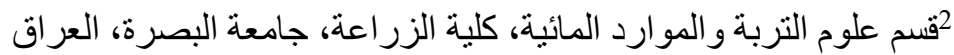

المستخلص: هنالك حاجة متزايدة لاجراء تقييم لزحف الرمال على الاراضي الزراعية باستخدام نظم المعلومات

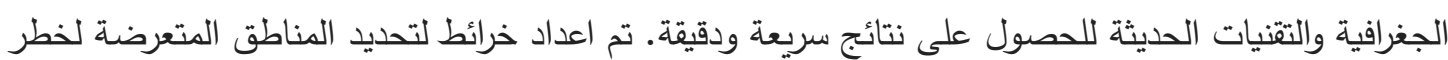
زحف الرمال في جنوب العراق اعتمادا على المعادلة العامة للتعرية الريحية (WEQ) ونظم المعلومات الجغرافية. تم اعتماد تقانات الاستشعار عن بعد (RS) و نظم المعلومات الجغرافية (GIS) و نظام تخديد الموقع (VPS) و تطبيقها مع الخرائط الطبوغرافية والمرئيات الفضائية الملتقطة في العام 2003 و 2006 ونتائج التحليل للمسح الحقلي. كل عوامل معادلة التعرية الريحية طبتت في قاعدة بيانات نظم المعلومات الجغرافية وتحويلهاعلى خرائط

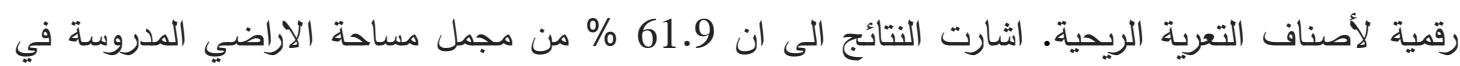
المنطقة الجنوبية للعراق تعاني من التعرية الثديدة مع تدهور في الغطاء النباتي. ويواجه العراق مشاكل تدهور بيئي خطيرة يجب معالجتها.وبعكسه ستكون هنالك صعوبة و تكلفة في معالجتها لاحقا. ان التذهور البيئي يثكل تهديد كبير للانسان و خاصة بين الفقراء. 